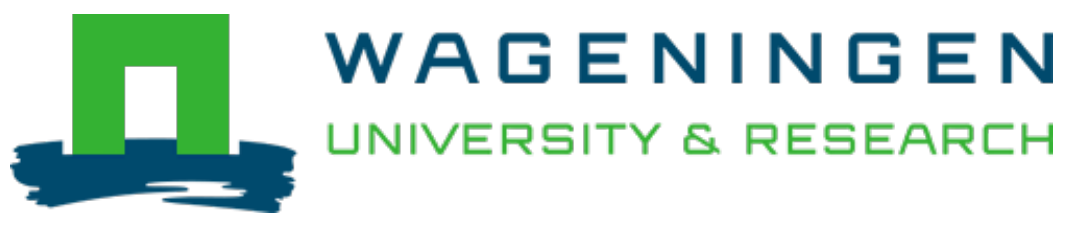

\author{
Biodiversity of yeasts from Illinois maize. \\ Canadian Journal of Microbiology \\ Nout, M.J.R.; Platis, C.E.; Wicklow, D.T. \\ https://doi.org/10.1139/m97-050
}

This publication is made publicly available in the institutional repository of Wageningen University and Research, under the terms of article $25 \mathrm{fa}$ of the Dutch Copyright Act, also known as the Amendment Taverne. This has been done with explicit consent by the author.

Article $25 \mathrm{fa}$ states that the author of a short scientific work funded either wholly or partially by Dutch public funds is entitled to make that work publicly available for no consideration following a reasonable period of time after the work was first published, provided that clear reference is made to the source of the first publication of the work.

This publication is distributed under The Association of Universities in the Netherlands (VSNU) 'Article $25 \mathrm{fa}$

implementation' project. In this project research outputs of researchers employed by Dutch Universities that comply with the legal requirements of Article $25 \mathrm{fa}$ of the Dutch Copyright Act are distributed online and free of cost or other barriers in institutional repositories. Research outputs are distributed six months after their first online publication in the original published version and with proper attribution to the source of the original publication.

You are permitted to download and use the publication for personal purposes. All rights remain with the author(s) and / or copyright owner(s) of this work. Any use of the publication or parts of it other than authorised under article $25 \mathrm{fa}$ of the Dutch Copyright act is prohibited. Wageningen University \& Research and the author(s) of this publication shall not be held responsible or liable for any damages resulting from your (re)use of this publication.

For questions regarding the public availability of this publication please contact openscience.library@,wur.nl 


\title{
Biodiversity of yeasts from Illinois maize
}

\author{
M.J.R. Nout, C.E. Platis, and D.T. Wicklow
}

\begin{abstract}
Microflora in wound sites of preharvest maize (including bacteria, yeasts, and filamentous fungi) may play a role in attracting insects to maize plants and may also interact with growth and mycotoxin production by filamentous fungi. As little data are available about the yeasts occurring on maize from the U.S. corn belt, samples of milled maize from experimental plantings at the University of Illinois River Valley Sand Field were analyzed. Yeast counts showed slight yearly fluctuation and varied between 3.60 and 5.88 ( $\log \mathrm{cfu} / \mathrm{g}$ maize). The majority of the yeasts were Candida guilliermondii (approximately 55\%), Candida zeylanoides (24\%), Candida shehatae (11\%), and Debaryomyces hansenii ( $3 \%$ ). Also present were Trichosporon cutaneum, Cryptococcus albidus var. aerius, and Pichia membranifaciens. The occurrence of killer yeasts was also evaluated. Killer yeasts were detected in maize for the first time and were identified as Trichosporon cutaneum and Candida zeylanoides. These were able to kill some representative yeasts isolated from maize, including Candida guilliermondii, Candida shehatae, and Cryptococcus albidus var. aerius. Other maize yeasts (Candida zeylanoides, Debaryomyces hansenii, Pichia membranifaciens) were not affected. The majority of yeasts found on maize were unable to ferment its major sugars, i.e., sucrose and maltose. Some (e.g., Candida zeylanoides) were not even able to assimilate these sugars. The importance of these properties in relation to insect attraction to preharvest ears of maize is discussed.
\end{abstract}

Key words: corn, maize, yeast, killer.

Résumé : Au stade de prérécolte du maïs, la microflore des sites de lésions (incluant les bactéries, les levures et les champignons filamenteux) peut jouer un rôle dans l'attraction des insectes chez les plants de maïs et aussi interagir avec la croissance et la production de mycotoxines par les champignons filamenteux. Comme il y a peu de données disponibles sur les levures survenant chez le maïs dans la région de culture du blé d'Inde aux É.-U., des échantillons de maïs moulu provenant de cultures expérimentales de la River Valley Sand Field de l'University of Illinois ont été analysés. Les numérations de levures ont montré une faible fluctuation annuelle et ont varié entre 3,60 et 5,88 ( $\log$ cfu/g maïs). Majoritairement, les levures ont été Candida guilliermondii (approximativement 55\%), Candida zeylanoides (24\%), Candida shehatae (11\%) et Debaryomyces hansenii (3\%). D'autres espèces étaient présentes : Trichosporon cutaneum, Cryptococcus albidus var. aerius et Pichia membranifaciens. L'occurrence de levures tueuses a aussi été évaluée. Détectées pour la première fois chez le maïs, elles ont été identifiées comme étant le Trichosporon cutaneum et le Candida zeylanoides. Ces dernières ont pu tuer certaines des levures représentatives isolées du maïs, incluant le Candida guilliermondii, le Candida shehatae et le Cryptococcus albidus var. aerius. Les levures qui n'ont pas été affectées sont le Candida zeylanoides, le Debaryomyces hansenii et le Pichia membranifaciens. La majorité des levures trouvées chez le maïs n'ont pu fermenter les principaux sucres soit le sucrose et le maltose. Certaines levures, comme le Candida zeylanoides, n'ont méme pas été capables d'assimiler ces sucres. L'importance de ces propriétés relativement à l'attraction des insectes sur les épis de maïs au stade de prérécolte est discutée.

Mots clés : blé d'Inde, maïs, levure, tueur.

[Traduit par la rédaction]

\section{Introduction}

Preharvest infection of maize with mycotoxin-producing kernel-rotting fungi has been associated with insect infestation of maize ears (Wicklow 1995). Sap beetles (Nitidulidae) may serve as vectors of Aspergillus flavus, Fusarium moniliforme, and Gibberella zea (anamorph state $=$ Fusarium graminearum) to preharvest maize (Windels et al. 1976;

Received October 2, 1996. Revision received December 9, 1996. Accepted December 10, 1996.

M.J.R. Nout. ${ }^{1}$ Department of Food Science, Agricultural University, Bomenweg 2, 6703 HD Wageningen, the Netherlands. C.E. Platis and D.T. Wicklow. National Center for Agricultural Utilization Research, U.S. Department of Agriculture, 1815 North University Street, Peoria, IL 61604, U.S.A.

1 Author to whom all correspondence should be addressed (e-mail: rob.nout@algemeen.lenm.wau.nl).
Attwater and Busch 1983; Lussenhop and Wicklow 1990). Lussenhop and Wicklow (1990) proposed that sap beetles are attracted to damaged maize ears by volatile fermentation products of wound-site microorganisms. Supporting evidence was provided by Dowd and Bartelt (1991), who demonstrated that specific yeast volatile metabolites synergize the attractiveness of the beetle aggregation pheromone. Yeasts are abundant on preharvest maize (Burmeister and Hartman 1966; Hesseltine and Bothast 1977). Freshly harvested highmoisture maize grown in Iowa contained about $10^{3}$ yeast cells/g, and Candida parapsilosis was the most frequently isolated yeast from fresh kernels (Burmeister and Hartman 1966). Hesseltine and Bothast (1977) showed that the number of kernels colonized by yeasts increases dramatically during the early stages of maturation in Illinois maize ( 8 weeks postsilk $=251$ of 300 kernels colonized). The authors argued that yeasts were superficial colonists of grain surfaces because few yeast colonies were detected following surface sterilization 
of grain samples. Horn (1985) reported Candida guilliermondii as the dominant yeast species in preharvest Georgia maize. Other yeasts, primarily species of Rhodotorula and Cryptococcus, accounted for $<1.0 \%$ of the total yeast population. Candida guilliermondii was confined mainly to kernels visibly moulded by filamentous fungi, primarily Fusarium moniliforme and Aspergillus flavus, in what Horn (1985) suggested is a commensalistic association.

The objectives of this research were to identify and quantify the yeasts occurring on Illinois maize at harvest and to investigate specific biochemical attributes that might enable different yeast strains to successfully colonize the maturing kernels in the presence of other microbes. Characterization of yeast assimilative and fermentative abilities may indicate patterns of resource use, potential species interactions (i.e., exploitation competition and commensalism), and production of volatile fermentation products. Killer yeasts were also examined, since they behave as interference competitors and may impact yeast community structure in maize, as has been reported for cactophilic yeast populations (Starmer et al. 1987; Ganter and Starmer 1992).

\section{Materials and methods}

\section{Field samples}

Yeast populations were isolated from maize kernels (Pioneer 3379) produced at the University of Illinois River Valley Sand Field (IRVSF), Kilbourne, Ill., in 1988-1991. In each of the 4 years, maize samples $(1.5 \mathrm{~kg})$ were separately combine harvested from each of 32 plots within an experimental planting $(<1.5$ acres; 1 acre $=0.404 \mathrm{ha})$ under continuous maize cultivation. In 1988, maize grown in field plot No. 20 produced no ears. Maize was harvested in October following natural dry-down (14-17\% kernel moisture) and stored at $-21^{\circ} \mathrm{C}$.

Subsamples of kernels $(500 \mathrm{~g})$ were ground using a Stein Mill (Seedboro Equipment Co., Chicago, Ill.) to enhance homogenous distribution of microorganisms, and dilutions were prepared in $0.02 \%$ water agar. In this type of mill, grinding did not result in significant heating of the maize. To collect predominant yeasts, pour plates were made of each final dilution $\left(10^{-4}\right)$ with potato dextrose agar (PDA) with $30 \mu \mathrm{g}$ streptomycin/L.

From dilution plates representing each ground sample, two colonies were randomly selected for identification. Of these, 220 were yeasts. They were purified on yeast malt (YM) agar ( $3 \mathrm{~g}$ yeast extract, $3 \mathrm{~g}$ malt extract, $5 \mathrm{~g}$ peptone, $10 \mathrm{~g}$ glucose, $15 \mathrm{~g}$ agar, $1 \mathrm{~L}$ distilled water) and stored in glycerol (1 mL glycerol $-1 \mathrm{~mL}$ yeast suspension) at $-21^{\circ} \mathrm{C}$.

\section{Enumeration of yeasts}

Enumeration of yeasts was performed in April 1995 on an arbitrarily chosen subsample of 12 ground maize samples representing maize harvested from three plots in each of the 4 years.

Decimal dilutions with peptone physiological salt solution (PPS: $1.0 \mathrm{~g}$ peptone, $8.5 \mathrm{~g} \mathrm{NaCl}, 1$ litre distilled water) were pour plated in YM agar with tetracycline (Sigma T- $3383,37.5 \mathrm{mg} / \mathrm{L}$ ). Yeast counts were calculated as number of colony-forming units per gram of sample and are reported as $\log \mathrm{cfu} / \mathrm{g}$.

\section{Preliminary grouping of isolates}

Yeast cultures grown on $\mathrm{YM}$ agar plates at $25^{\circ} \mathrm{C}$ for 3 days were sorted on the basis of their colony morphology, including smoothness of surface, regularity of border, consistency, colour, and occasionally, smell. At a later stage, assimilation (glucose, galactose, melibiose) and fermentation (glucose, galactose) of key carbohydrates, selected on the basis of homogenous assimilation and fermentation patterns by fully identified yeast strains, served as additional criteria for grouping of isolates.

\section{Identification}

From each group of isolates, a representative number $(1-6)$ of isolates (27 in total) were further tested, keyed out, and identified (Wickerham 1951; Kreger-Van Rij 1984; Barnett et al. 1990). The protocol included tests for the following: (i) assimilation $\left(25^{\circ} \mathrm{C}\right.$ after 7,21 , and 28 days in broth) of 45 sources of $\mathrm{C}$ and $\mathrm{N}$; (ii) ability to degrade gelatin, grow at reduced water activity, grow at 37 and $5^{\circ} \mathrm{C}$, and grow in the presence of 100 and $1000 \mathrm{ppm}$ cycloheximide; (iii) fermentation $\left(28^{\circ} \mathrm{C}\right.$ after $1,2,4,6,8,12,16$, 20 , and 24 days in broth) of seven carbohydrates; (iv) ascospore formation; (v) pseudomycelium formation; (vi) formation of pellicles or rings on assimilation broth.

\section{Detection of killer yeasts}

Cross-reactions (Rogers and Bevan 1978) were carried out on killer medium (KM: $10 \mathrm{~g}$ yeast extract, $10 \mathrm{~g}$ peptone, $20 \mathrm{~g}$ glucose, $20 \mathrm{~g}$ agar, $110 \mathrm{~mL}$ of $1 \mathrm{M} \mathrm{K}_{2} \mathrm{HPO}_{4}$ - citric acid buffer ( $\mathrm{pH} 4.5$ ), $30 \mathrm{mg}$ methylene blue, $1 \mathrm{~L}$ distilled water). Highly sensitive strains were used as indicators and included Candida guilliermondii (K2-UCSC $=$ NRRL Y $17887=\mathrm{LU} 120)$, Candida maltosa $($ K23-UCSC $=$ NRRL Y $17888=$ LU125), and Pichia anomala $($ K3-UM(2) $=$ NRRL Y $17901=$ LU536), kindly provided by Dr. L. Polonelli, University of Parma, Italy; Pichia amethionina var. pachycereana $(80-314.1=$ NRRL Y $17779=\mathrm{LU} 1201)$ and Williopsis californica $(85-756.1=$ NRRL Y $17720=$ LU750) kindly provided by Dr. W.T. Starmer, Syracuse University, Syracuse, N.Y.; Candida tenuis (NRRL Y 17768), kindly provided by Dr. C.L. Wilson, ARS Appalachian Fruit Research Station, Kearneysville W.Va.; Sacharomyces cerevisiae (CBS5495 $=$ NRRL Y $17890=$ LU322, NRRL Y $17893=$ LU325, and NRRL Y $17895=$ LU328), Candida glabrata $($ NCYC388 = NRRL Y $17256=$ LU020), Cryptococcus cereanus (CBS2779 = NRRL Y $17778=$ LU135), and Kluyveromyces lactis var. lactis $($ CBS2896 = NRRL Y $17889=$ LU270).

Suspensions of indicator strains were made in PPS, and $0.15 \mathrm{~mL}$ was spread on a $15 \times 15 \mathrm{~cm}$ square KM plate followed by a 30 -min drying period (ambient temperature, laminar flow hood). Using a sterile stamping device, 25 unknowns were deposited as thick spots ( $2 \mathrm{~mm}$ diameter) followed by incubation at 25 and $28^{\circ} \mathrm{C}$ for $3-$ 5 days. Results were categorized as three types: (i) negative (confluent growth of indicator strain and spot without colour effects); (ii) intermediate kill (spot surrounded by clear inhibition zone without blue edge or indicator turned blue without inhibition zone); (iii) complete kill (spot surrounded by clear inhibition zone lined with blue ring of dead indicator cells).

\section{Effect of maize killer yeasts on other maize yeasts}

Using the technique for detection of killer yeasts, representative yeast isolates from maize were spread on KM and spotted with maize killer yeasts.

\section{Statistics}

Analysis of variance and chi-square analysis were used (Snedecor and Cochran 1989).

\section{Results and discussion}

The numbers of yeasts in 12 representative grain samples are presented in Table 1. Analysis of variance showed a significant $(p<0.05)$ year effect but no plot effect. Even so, the counts recorded are typical for unprocessed maize grains 
Table 1. Yeast counts in three selected plots of maize grain (Pioneer 3379) harvested at the University of Illinois River Valley Sand Field, Kilbourne, Ill. $(1988-1991)(\log \mathrm{cfu} / \mathrm{g})$.

\begin{tabular}{ccccc}
\hline & \multicolumn{4}{c}{ Harvest year } \\
\cline { 2 - 5 } Plot No. & 1988 & 1989 & 1990 & 1991 \\
\hline 7 & 4.48 & 5.00 & 3.70 & 4.19 \\
19 & 4.44 & 5.24 & 3.93 & 5.54 \\
31 & 3.48 & 5.88 & 3.60 & 4.78 \\
\hline
\end{tabular}

(Middelhoven and Van Baalen 1988; Hounhouigan et al. 1994). A total of 220 yeast strains were isolated from ground maize. The purified strains were grouped according to their macroscopic morphology and other properties such as growth rate and smell. The large majority of yeasts had a smooth surface, regular colony margins, buttery consistency, and white to creamy color with a pleasant yeasty smell. Within each group, one or more representative strains were subjected to full identification procedures, based on physiological, genetic (ascospore production) and metabolic properties (Kreger-Van Rij 1984). Taking into account the profile of assimilation and fermentation abilities of the identified strains, a shortened approach was taken to screen all 220 isolates based on the assimilation of glucose, galactose, melibiose, sucrose, and maltose, and fermentation of glucose, galactose, sucrose, and maltose. The results show a consistent pattern of species abundance for the three prevalent yeast species (Candida guilliermondii, Candida zeylanoides, and Candida shehatae) for all years (Table 2). This was supported by chi-square analysis that revealed nonsignificant effects of year of harvest on species abundance. Other species of limited occurrence, including Cryptococcus albidus var. aerius, Debaryomyces hansenii, Pichia membranifaciens, and Trichosporon cutaneum, suggest a structured yeast community in maize produced at the IRVSF. For some species, strains with different properties were observed. Of Candida guilliermondii, three strains (A, B, and C) were distinguished that differed in assimilation of lactose, L-rhamnose, calcium 2-keto-D-gluconate, and lactic acid. Of Candida shehatae, two strains (A and B) were distinguished with different assimilation (lactose, raffinose, L-arabinose, D-arabinose, D-ribose, D-glucosamine $\cdot \mathrm{HCl}$, dulcitol, potassium D-gluconate), fermentation (maltose, sucrose, lactose, raffinose, trehalose), and growth temperature patterns $\left(5\right.$ and $\left.37^{\circ} \mathrm{C}\right)$. Of Candida zeylanoides, five strains (A, B, C, D, and E) were distinguished with different assimilation patterns (cellobiose, soluble starch, $\alpha$-methyl D-glucoside, salicin, pyruvic acid). Of T. cutaneum, three strains (A, B, and C) were distinguished with different assimilation patterns (D-arabinose, L-rhamnose, D-mannitol).

The occurrence of Candida guilliermondii as the most prevalent yeast species confirms an earlier finding (Horn 1985), but the significant presence of Candida zeylanoides and Candida shehatae in North American maize has not been recorded before. Candida zeylanoides has been reported from processed foods and Candida shehatae was described as an insect-associated yeast (Kreger-Van Rij 1984). The 40-acre IRVSF is surrounded by natural forested habitats,
Table 2. Occurrence of yeast species in maize grain (Pioneer 3379) harvested from 32 plots at the University of Illinois River Valley Sand Field, Kilbourne, Ill. (1988-1991).

\begin{tabular}{lcccc}
\hline & \multicolumn{4}{c}{ No. of identified isolates ${ }^{a}$} \\
\cline { 2 - 5 } \multicolumn{1}{c}{ Yeasts } & 1988 & 1989 & 1990 & 1991 \\
\hline Candida guilliermondii & $30(49 \%)$ & $38(64 \%)$ & $31(63 \%)$ & $23(43 \%)$ \\
Candida zeylanoides & $18(30 \%)$ & $10(17 \%)$ & $6(12 \%)$ & $19(36 \%)$ \\
Candida shehatae & $10(16 \%)$ & $5(9 \%)$ & $4(8 \%)$ & $6(11 \%)$ \\
Debaryomyces hansenii & $1(2 \%)$ & $2(3 \%)$ & $2(4 \%)$ & $1(2 \%)$ \\
Trichosporon cutaneum & - & $1(2 \%)$ & $2(4 \%)$ & - \\
Cryptococcus albidus & & & & \\
$\quad$ var. aerius & - & - & $1(2 \%)$ & $1(2 \%)$ \\
Pichia membranifaciens & - & $2(3 \%)$ & - & - \\
Unidentified species & $2(3 \%)$ & $1(2 \%)$ & $1(2 \%)$ & $3(6 \%)$ \\
Total yeasts & 61 & 59 & 47 & 53 \\
\hline
\end{tabular}

${ }^{a}$ The percentages of the total yeast isolates are given in parentheses.

and large numbers of sap beetles, chiefly Carpophilus lugubris, migrate from these forests each summer to colonize the ripening maize ears (Dowd et al. 1992). This could explain the prevalence of Candida shehatae in maize grain samples from IRVSF. Of the less prevalent yeasts, $D$. hansenii (Roostita and Fleet 1996) and Trichosporon spp. (Nout 1991) have been reported from fermented foods, Cryptococcus albidus was observed as a major yeast in wheat (Kurtzman et al. 1970), and P. membranifaciens was isolated from wine (Mora and Rosello 1992). As most yeasts do not readily degrade starch, they depend on mono- and di-saccharides as sources of carbon and energy. The nature of available carbohydrates plays a role in the selection of dominating yeasts, as was demonstrated in fermented food of plant origin, e.g., sourdough (Gobbetti et al. 1994) and sugary kefir (Leroi and Pidoux 1993). Major sugars in preharvest maize are sucrose, glucose, fructose, and potentially maltose when starch is degraded. During the developmental stages of the kernel, the levels of sucrose, glucose, and fructose decrease from 23 , 12 , and $9 \% \mathrm{w} / \mathrm{w}$, respectively, 10 days postpollination, to 2 , 0 , and $0 \% \mathrm{w} / \mathrm{w}$, respectively, in ripe-harvested kernels (Doehlert et al. 1993). Within the kernel, the highest sugar levels occur in the base, pericarp, and embryo, with relatively low levels in the endosperm (Doehlert and Kuo 1990). No data are available on maltose levels; these depend on the presence and activity of amylolytic enzymes. Of the isolated yeasts, most are able to assimilate glucose, sucrose, and maltose. However, Candida zeylanoides and $P$. membranifaciens assimilate sucrose and maltose only weakly. These two species probably depend on mutualistic relationships, with microorganisms or insects providing assimilable metabolites. Horn (1985) presents evidence that the association between Candida guilliermondii and amylolytic filamentous fungi on preharvest corn is probably commensalistic, with Candida guilliermondii utilizing the starch hydrolyzates produced by such fungi. Pichia burtonii is one of the few yeasts that produces extracellular amylase (Kreger-Van Rij 1984). Burmeister and Hartman (1966) found that after ensilage of high moisture maize kernels for 7 days, Candida guillermondii was replaced by $P$. burtonii, Hansenula anomala (= Pichia anomala), and Candida krusei as the most com- 
monly recorded yeasts. While these replacement yeasts were not recorded at harvest, they probably had a limited presence.

Although most of the yeasts isolated from maize ferment glucose, this sugar is not available in large quantities in maize grain. As most maize-associated yeasts only ferment glucose, production of fermentation volatiles by yeasts in maize wound sites would be limited. Only Candida shehatae is able to ferment sucrose and maltose. The production of volatile fermentation products could make Candida shehatae attractive to sap beetles or other maize insects. A low fermentation activity of prevalent yeasts, with irregular distribution of a minority of fermenting yeasts, may partly explain why in maize fields substantial numbers of nitidulid beetles were recorded from certain wounded maize ears, while few or no nitidulid beetles were found on similarly wounded maize ears from within the same row planting (Lussenhop and Wicklow 1990).

Hesseltine and Bothast (1977) demonstrated that bacteria were the initial colonists of maize ears, followed by the appearance of yeasts which the authors associated with dispersal by maize insects. Injured cactus tissue is also first infected by bacteria from the plant tissue or aerosols and (or) dust, resulting in a necrosis in which cactophilic yeasts are secondary invaders (Fogleman and Foster 1989). These necroses provide substrates for feeding and breeding by icactophilic Drosophila species (Fellows and Heed 1972), which serve as vectors for bacteria and yeasts, thus contributing to species distribution patterns (Starmer 1982; Fogleman and Foster 1989). Variations in the distribution of yeast species among different cactus necroses reflected different successional states (Starmer 1982; Starmer and Fogleman 1986). A more uniform distribution of yeasts may be present in maize grain at harvest, since the grain is at the same state of physiological maturity and moisture content, and wounding thus takes place in a relatively narrow time span.

Using 12 highly sensitive yeast strains as indicators, 4 strains of killer yeasts were detected among the 220 yeast isolates from maize. The occurrence of killer yeasts in preharvest maize has not been previously reported. The patterns of killing ability for three strains of $T$. cutaneum and strain $\mathrm{E}$ of Candida zeylanoides are presented in Table 3. The sensitivity of some indicator strains was markedly influenced by the incubation temperature $\left(25\right.$ versus $\left.28^{\circ} \mathrm{C}\right)$. The killer reaction on agar media is the result of several factors, including the diffusion rate of killer toxins, growth rates, and temperature-related stress of test and lawn strains. We do not know which of these factors prevailed in our experiment, but for practical purposes it would indicate that killer tests at different temperatures provide additional information on yeast interactions. Trichosporon cutaneum killed a greater number of the indicator strains than Candida zeylanoides. Within T. cutaneum, the pattern of killing for strain A was markedly different from that of strains B and C. Strain C of $T$. cutaneum can be distinguished from strain B by its ability to kill Candida glabrata at $28^{\circ} \mathrm{C}$. Strains B and C of $T$. cutaneum could also be separated by their ability to assimilate D-arabinose, L-rhamnose, and D-mannitol.

The four strains of killer yeast from maize were also tested for their ability to kill a group of 18 representative maize yeasts (Table 3). Strains of $T$. cutaneum (NRRL Y $17868=$ LU697, NRRL Y 17874 = LU696, and NRRL Y
$17875=$ YM6-7) killed Candida guilliermondii (6 of 7 strains), Candida shehatae (1 of 2 strains), and Cryptococcus albidus (1 of 1 strain). The other killer yeast, Candida zeylanoides E (NRRL Y $17886=$ LU029), showed a much narrower spectrum of activity, killing Candida shehatae ( 1 of 2 strains) and Cryptococcus albidus (1 of 1 strain), but fewer strains ( 2 of 7 ) of Candida guilliermondii. Candida zeylanoides (five strains), D. hansenii (two strains), and $P$. membranifaciens (one strain) were not sensitive to killer strains from maize. Cryptococcus albidus var. aerius (NRRL. Y $17876=$ LU134) and Candida shehatae (NRRL Y $17880=$ LU025) were killed by each of the maize killer yeasts at 25 and $28^{\circ} \mathrm{C}$. Cryptococcus albidus (NRRL Y $17876=$ LU134) might be used as a bioassay strain to detect killer yeasts in grain in the same way that Candida glabrata (Y-55 = NRRL Y 17256) has been used to screen for killer strains of cactophilic yeasts (Starmer et al. 1987). Kurtzman et al. (1970) reported the common occurrence of Cryptococcus albidus, Cryptococcus laurentii, Rhodotorula glutinis, Pichia fermentans, and $P$. burtonii in unmilled wheat, and of H. anomala, Pichia farinosa, $P$. burtonii, Saccharomyces microellipsoides, and Candida spp. in wheat flour.

Sensitivity to maize killer yeast strains does not by itself explain the common occurrence of Cryptococcus albidus in wheat and a limited occurrence in Illinois maize. Similarly, the ability to kill Candida guilliermondii has not resulted in $T$. cutaneum becoming a dominant maize yeast (Table 2). Killer activity as detected in laboratory media is limited within sometimes narrow ranges of $\mathrm{pH}$ and temperature. We do not know whether the killer character of, e.g., T. cutaneum, as detected in KM agar is also active in maize kernels. Petering et al. (1991) recognized the importance of fermentation conditions for effective killer activity in wine production. In laboratory experiments, complete elimination of sensitive cells was not achieved, even at a $2: 1$ ratio of killer to sensitive cells. The fact that $T$. cutaneum is not a fermenting yeast may decrease its chances of insect-mediated dispersal in nature. Weakly or nonfermenting yeasts, T. cutaneum and Cryptococcus albidus, were predominant among isolates from vegetable origin in a survey of yeasts isolated from samples of fruit and vegetables (King and Torok 1992). In contrast, Candida zeylanoides occurs much more frequently than $T$. cutaneum in Illinois maize ( $24 \%$ of all isolates), yet only 1 of 53 strains tested showed killer activity. Samples of combine-harvested maize include individual mould- and insect-damaged grains. We did not determine the distribution of yeast strains among these individual grains. Yeast strains with limited occurrence in grain samples may have been the dominant colonist of one damaged grain.

Ganter and Starmer (1992) argued that the only possible function for yeast killer factors in natural habitats is as a mechanism of interference competition. Killer yeasts from Drosophila-associated yeast habitats (e.g., discrete pockets of rotting cactus tissue, sap-fluxes, and fruit) were more likely to kill species from other habitats than from their own habitat, suggesting some adaptation within a yeast community to the killer toxins present (Starmer et al. 1987; Ganter and Starmer 1992). The different yeast biotypes recorded from grain samples could suggest that insects carried these yeasts into the corn field from diverse microhabitats in adjoining oak woodlands (Dowd et al. 1992). 
Table 3. Killing pattern of killer yeasts isolated from maize grain (Pioneer 3379) harvested from 32 plots at the University of Illinois River Valley Sand Field, Kilbourne, Ill. (1988-1991).

\begin{tabular}{|c|c|c|c|c|c|c|c|c|}
\hline \multirow[b]{3}{*}{ Sensitive indicator strains } & \multicolumn{8}{|c|}{ Killer yeasts } \\
\hline & \multicolumn{2}{|c|}{$\begin{array}{c}\text { T. cutaneum A } \\
\text { (NRRL Y } 17868=\text { LU697) }\end{array}$} & \multicolumn{2}{|c|}{$\begin{array}{c}\text { T. cutaneum B } \\
\text { (NRRL Y } 17874=\text { LU696) }\end{array}$} & \multicolumn{2}{|c|}{$\begin{array}{c}T . \text { cutaneum C } \\
\text { (NRRL Y } 17875=\text { YM6-7) }\end{array}$} & \multicolumn{2}{|c|}{$\begin{array}{c}\text { C. zeylanoides } \mathrm{E} \\
(\mathrm{NRRL} \mathrm{Y} 17886=\mathrm{LU} 029\end{array}$} \\
\hline & $25^{\circ} \mathrm{C}$ & $28^{\circ} \mathrm{C}$ & $25^{\circ} \mathrm{C}$ & $28^{\circ} \mathrm{C}$ & $25^{\circ} \mathrm{C}$ & $28^{\circ} \mathrm{C}$ & $25^{\circ} \mathrm{C}$ & $28^{\circ} \mathrm{C}$ \\
\hline \multicolumn{9}{|l|}{ Candida guilliermondii } \\
\hline (NRRL Y 17887 = LU120) & 0 & - & & o & & 0 & - & 0 \\
\hline $\begin{array}{l}\text { Candida maltosa } \\
\quad(\text { NRRL Y } 17888=\text { LU125) }\end{array}$ & . & & 0 & - & 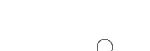 & 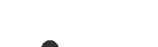 & 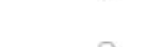 & \\
\hline & & & 0 & 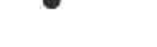 & 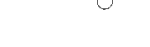 & 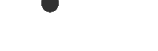 & 0 & \\
\hline (NRRL Y $17890=$ LU322) & & & 0 & o & 0 & $\circ$ & 0 & \\
\hline $\begin{array}{l}\text { Saccharomyces cerevisiae } \\
\text { (NRRL Y } 17893=\text { LU325) }\end{array}$ & 0 & 0 & 0 & 0 & . & & & \\
\hline Saccharomyces cerevisiae & & & & & 0 & 0 & & \\
\hline $\begin{array}{l}\text { (NRRL Y } 17895=\text { LU328) } \\
\text { Pichia anomala }\end{array}$ & $\bullet$ & $\bullet$ & 0 & 0 & o & $\circ$ & & \\
\hline $\begin{array}{l}\text { (NRRL Y } 17901 \text { = LU536) } \\
\text { Candida glabrata }\end{array}$ & & & 0 & & 0 & & & \\
\hline $\begin{array}{l}\text { (NRRL Y } 17256=\text { LU020) } \\
\text { Candida temuis }\end{array}$ & 0 & & 0 & & 0 & 0 & & \\
\hline (NRRL Y 17768) & 0 & - & & 0 & & 0 & & \\
\hline $\begin{array}{l}\text { Cryptococcus cereanus } \\
\text { (NRRL Y } 17778=135)\end{array}$ & & & & & & & & \\
\hline $\begin{array}{l}\text { (NRRL Y } 17778=\text { LU135) } \\
\text { Kluyveromyces lactis var. lactis } \\
\text { (NRRL Y } 17889=\text { LU270) }\end{array}$ & 0 & & 0 & 0 & 0 & 0 & & \\
\hline $\begin{array}{l}\text { Pichia amethionina } \\
\text { var. pachycereana } \\
\text { (NRRL Y } 17779=\text { LU1201) }\end{array}$ & 0 & & & & & & & \\
\hline Williopsis californica & & & & & & & & \\
\hline$($ NRRL Y $17720=$ LU750) & 0 & 0 & & & & & & \\
\hline \multicolumn{9}{|c|}{ Yeast isolates from preharvest maize } \\
\hline Candida guilliermondii A & & & & & & & & \\
\hline $\begin{array}{l}\text { (NRRL Y } 17860=\text { YM1-2) } \\
\text { Candida guilliermondii } \mathrm{A}\end{array}$ & & 0 & & 0 & & 0 & & a \\
\hline $\begin{array}{l}\text { (NRRL Y } 17861=\text { LU021) } \\
\text { Candida puilliermondii A }\end{array}$ & & & & O & & 0 & & \\
\hline$($ NRRL Y $17867=$ YM3-8) & & 0 & & 0 & & 0 & & \\
\hline Candida guilliermondii $\mathrm{B}$ & & & & & & 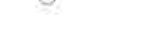 & & \\
\hline $\begin{array}{l}\text { (NRRL Y } 17870=\text { LU022) } \\
\text { Candida guilliermondii B }\end{array}$ & & $\bullet$ & & - & & - & & \\
\hline$($ NRRL Y $17883=$ YM9-12) & & $\circ$ & & o & & 0 & & \\
\hline Candida guilliermondii $\mathrm{C}$ & & & & & & & & \\
\hline $\begin{array}{l}\text { (NRRL Y } 17881=\text { LU023) } \\
\text { Candida shehatae B }\end{array}$ & & 0 & & 0 & 0 & 0 & 0 & \\
\hline (NRRL Y $17880=$ LU025) & $\bullet$ & $\bullet$ & o & $\bullet$ & 0 & $\bullet$ & 0 & $\bullet$ \\
\hline $\begin{array}{l}\text { Cryptococcus albidus var. aerius } \\
\text { (NRRL Y } 17876=\text { LU134) }\end{array}$ & $\bullet$ & - & $\bullet$ & 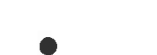 & e & e & 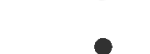 & - \\
\hline
\end{tabular}


Such microhabitats have not been identified nor have the resident yeast populations been characterized. It is not known whether the less abundant yeast species are ineffective competitors in the wound sites of preharvest maize or are simply less commonly carried to maize by insects such as Candida lugubris.

This study has served to characterize the yeast community of preharvest maize from a field in central Illinois. The prevalence of Candida guilliermondii, Candida zeylanoides, and Candida shehatae is only partially explained by the data and there is not sufficient data to explain the limited occurrence of $T$. cutaneum, Cryptococcus albidus, and $D$. hansenii. What has emerged from these studies are a number of ecological questions about the origin and ecology of the species populations, in habitats within and external to the maize field. In particular, further research is required to establish whether relationships exist between ecological interactions involving yeasts, and the extent to which the ears become damaged by insects or rotted by mycotoxin-producing fungi.

\section{Acknowledgements}

We thank C.P. Kurtzman for providing NRRL strains and advice on identifications. This project was supported by the U.S. Department of Agriculture/Foreign Agricultural Service/ International Cooperation and Development/Exchange Program and the Wageningen Landbouw Export Bureau fund.

\section{References}

Attwater, W.A., and Busch, L.V. 1983. Role of the sap beetle Glischrochilus quadrisignatus in the epidemiology of Gibberella corn ear rot. Can. J. Plant Pathol. 5: 158-163.

Barnett, J.A., Payne, R.W., and Yarrow, D. 1990. Yeasts: characteristics and identification. Cambridge University Press, Cambridge, U.K.

Burmeister, H.R., and Hartman, P.A. 1966. Yeasts in ensiled highmoisture corn. Appl. Microbiol. 14: 35-38.

Doehlert, D.C., and Kuo, T.M. 1990. Sugar metabolism in developing kernels of starch-deficient endosperm mutants of maize. Plant Physiol. 92: 990-994.

Doehlert, D.C., Kuo, T.M., Juvik, J.A., Beers, E.P., and Duke, S.H. 1993. Characteristics of carbohydrate metabolism in sweet corn (sugary-1) endosperms. J. Am. Soc. Hort. Sci. 118: $661-666$.

Dowd, P.F., and Bartelt, R.J. 1991. Host-derived volatiles as attractants and pheromone synergists for dried fruit beetle, Carpophilus hemipterus. J. Chem. Ecol. 17: 285-308.

Dowd, P.F., Bartelt, R.J., and Wicklow, D.T. 1992. A novel insect trap useful in capturing sap beetles (Coleoptera: Nitidulidae) and other flying insects. J. Econ. Entomol. 85: $772-778$.

Fellows, D.P., and Heed, W.B. 1972. Factors affecting host plant selection in desert-adapted cactiphilic Drosophila. Ecology, 53: $850-858$.

Fogleman, J.C., and Foster, J.L.M. 1989. Microbial colonization of injured cactus tissue (Stenocereus gummosus) and its relationship to the ecology of cactophilic Drosophila mojavensis. Appl. Environ. Microbiol. 55: 100-105.

Ganter, P.F., and Starmer, W.T. 1992. Killer factor as a mechanism of interference competition in yeasts associated with cacti. Ecology, 73: 54-67.

Gobbetti, M., Corsetti, A., and Rossi, J. 1994. The sourdough microflora. Interactions between lactic acid bacteria and yeasts: metabolism of carbohydrates. Appl. Microbiol. Biotechnol. 41: $456-460$.

Hesseltine, C.W., and Bothast, R.J. 1977. Mold development in ears of corn from tasseling to harvest. Mycologia, 69: $328-340$.

Horn, B.W. 1985. Association of Candida guilliermondii with amylolytic filamentous fungi on pre-harvest corn. Can. J, Microbiol. 31: 19-23.

Hounhouigan, D.J., Nout, M.J.R., Nago, C.M., Houben, J.H., and Rombouts, F.M. 1994. Microbiological changes in mawe during natural fermentation. World J. Microbiol. Biotechnol. 10: $410-413$.

King, A.D., and Torok, T. 1992. Comparison of yeast identification methods. In modern methods in food mycology. Dev. Food Sci. 31: 39-46.

Kreger-Van Rij, N.J.W. 1984. The yeasts, a taxonomic study. 3rd ed. Elsevier Science Publishers B.V., Amsterdam.

Kurtzman, C.P., Wickerham, L.J., and Hesseltine, C.W. 1970. Yeasts from wheat and flour. Mycologia, 62: 542-547.

Leroi, F., and Pidoux, M. 1993. Detection of interactions between yeasts and lactic acid bacteria isolated from sugary kefir grains. J. Appl. Bacteriol. 74: 48-53.

Lussenhop, J., and Wicklow, D.T. 1990. Nitidulid beetles (Nitidulidae: Coleoptera) as vectors of Aspergillus flavus in pre-harvest maize. Trans. Mycol. Soc. Jpn. 31: 63-74.

Middelhoven, W.J., and Van Baalen, A.H.M. 1988. Development of the yeast flora of whole-crop maize during ensiling and during subsequent aerobiosis. J. Sci. Food Agric. 42: 199-207.

Mora, J., and Rossello, C. 1992. The growth and survival of Pichia membranaefaciens during fermentation of grape juice. Am. J. Enol. Vitic. 43: 329-332.

Nout, M.J.R. 1991. Ecology of accelerated natural lactic fermentation of sorghum-based infant food formulas. Int. J. Food Microbiol. 12: $217-224$.

Petering, J.E., Symons, M.R., Langridge, P., and Henschke, P.A. 1991. Determination of killer yeast activity in fermenting grape juice by using a marked Saccharomyces wine yeast strain. Appl. Environ. Microbiol. 57: 3232-3236.

Rogers, D., and Bevan, E.A. 1978. Group classification of killer yeasts based on cross-reactions between strains of different species and origin. J. Gen. Microbiol. 105: 199-202.

Roostita, R., and Fleet, G.H. 1996. The occurrence and growth of yeasts in Camembert and Blue-veined cheeses. Int. J. Food Microbiol. 28: 393-404.

Snedecor, W.G., and Cochran, W.G. 1989. Statistical methods. 8th ed. Iowa State University Press, Ames, Iowa.

Starmer, W.T. 1982. Analysis of community structure of yeasts associated with the decaying stems of cactus. I. Stenocereus gummosus. Microb. Ecol. 8: $71-81$.

Starmer, W.T., and Fogleman, J.C. 1986. Coadaptation of Drosophila and yeasts in their natural habitat. J. Chem. Ecol. 12: $1037-1055$.

Starmer, W.T., Ganter, P.F., Aberdeen, V., Lachance, M.-A., and Phaff, H.J. 1987. The ecological role of killer yeasts in natural communities of yeasts. Can. J. Microbiol. 33: 783-796.

Wickerham, L.J. 1951. Taxonomy of yeasts. United States Department of Agriculture, Washington, D.C. Tech. Bull. No. 1029.

Wicklow, D.T. 1995. The mycology of stored grain: an ecological perspective. In Stored-grain ecosystems. Edited by D.S. Jayas, N.D.G. White, and W.E. Muir. Marcel Dekker, New York. pp. 197-249.

Windels, C.E., Windels, M.B., and Kommedahl, T. 1976. Association of Fusarium species with picnic beetles on corn ears. Phytopathology, 66: 328-331. 